\title{
INFRASTRUCTURE SUPPORT FOR THE DEVELOPMENT OF REGIONAL ECONOMIC SYSTEMS
}

\author{
Marat R. Safiullin ${ }^{1}$ \\ Azat R. Kadyrov ${ }^{2}$ \\ Gulnaz M. Galeeva ${ }^{3}$
}

\begin{abstract}
This article considers the problems of infrastructure financing, which is necessary for the successful development of regional economic systems. To identify the current problems in the development of investment attractiveness of the Russian regions, we selected the following factors: availability and level of provision of industrial, social, transport, and other infrastructure with facilities, government expenses on the creation and development of regional infrastructure. The study consists of several stages and is based on data published on the official websites of the World Bank, Gazprombank, the Ministry of Economic Development of the Russian Federation, and the Ministry of Regional
\end{abstract} Development of the Russian Federation. The study shows that the absolute leaders in terms of infrastructure investments are such countries as China, the United States, and India. In the total amount of infrastructure investments, transport infrastructure and telecommunications have an absolute advantage. In recent years, one of the development priorities of the Russian regions has been investing in physical culture and sports infrastructure facilities. This is due to major international sporting events and increasing the investment attractiveness of the regions. An important trend in the development of infrastructural support for the development of regional economic systems has been the conclusion of international investment transactions (IIT) and regional agreements. Most countries and regions, leading in the inflow of foreign direct investment, are the leaders in terms of

\footnotetext{
${ }^{1}$ Kazan Federal University. e-mail: Marat.Safiullin@tatar.ru. Tel. (843) 233-72-77.

${ }^{2}$ Center for Advanced Economic Research of the Academy of Sciences of the Republic of Tatarstan .email: cpei@mail.ru.Tel.2387935

${ }^{3}$ Kazan Federal University.e-mail: Marat.Safiullin@tatar.ru. Tel. (843) 233-72-77
} 
infrastructure development at the same time.

Keywords: infrastructure, region, regional development, infrastructure projects, investments, sports infrastructure.

\section{Introduction}

The world experience in financing the improvement of regional development infrastructure shows the priority of this area of investment, due to the infrastructure's ability to stimulate economic growth of both individual regions and countries as a whole. Thus, an increase in the infrastructure investments can lead to an increase in the number of jobs, an increase in the rate of economic turnover and an improvement in the quality of life of the population in the short, medium and long term, respectively.

In addition, a balanced infrastructure system is able to increase mobility of the population, which leads to optimization of the labor market structure, an overall increase in population incomes and stimulation of economic growth through an increase in effective demand. Currently, the value of Russia's infrastructure assets is about
$60 \%$ of GDP, while the recommended level of this indicator is $70 \%$ to maintain the necessary level of the country's infrastructure. Consequently, the infrastructure investments shall be increased at a faster pace. Today, Russia's share in the total global investment in infrastructure is about $3 \%$.

\section{Methods}

It should be noted that all countries and regions lack infrastructure financing today. In various countries, the volume of underfunding ranges from 20 to $40 \%$.

Based on the historical volume of infrastructure investments for the last 18 years, averaging $3.5-3.8 \%$ of GDP worldwide, as well as taking into account the critically low level of infrastructure financing in Russia and the outstripping growth in demand for infrastructure, it can be assumed that the minimum required volume of investments in Russian infrastructure in the period until 2030 will amount to $5 \%$ of the country's GDP.

The infrastructure of Russia is one of the most diverse in the world; it combines roads and railways, airports, ports, pipelines, energy (including 
nuclear), and water supply. One of the most acute problems of infrastructure development in the Russian regions is the high level of its depreciation. investments in global infrastructure is currently accounted for by roads (Fig. 1). The ports are in the last place under this indicator [1].

\section{Results and discussion}

The largest share of total

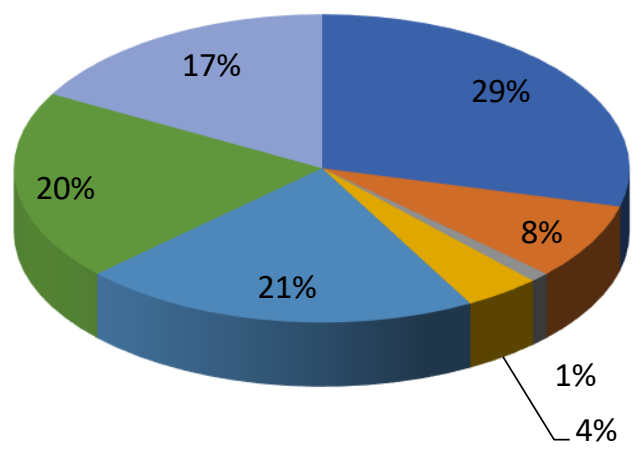

- Car roads

Railways

Ports

Airports

Power industry

Water supply

- Telecommunications

Fig. 1. The structure of the infrastructure investments of the world in the context of investment objects

The state budgets and funds remain the main source of infrastructure (over 65\%), formed from tax revenues, financing in the world (Table 1). excise taxes or national welfare funds

Table 1

The structure of infrastructure investments in the world by sources of financing [2]

\begin{tabular}{|l|c|c|}
\hline \multicolumn{1}{|c|}{ Source of financing } & $\begin{array}{c}\text { Volume of investments, } \\
\text { billinan dnomo }\end{array}$ & structure, \% \\
\hline State budgets and funds & 1350 & 65,4 \\
\hline
\end{tabular}




\begin{tabular}{|l|c|c|}
\hline Bank loans & 160 & 7,7 \\
\hline $\begin{array}{l}\text { Loans from international } \\
\text { financial arcanizatione }\end{array}$ & 25 & 1,2 \\
\hline $\begin{array}{l}\text { Share capital of infrastructure } \\
\text { Ommanioc }\end{array}$ & 40 & 1,9 \\
\hline $\begin{array}{l}\text { Own funds of infrastructure } \\
\text { ammanioc }\end{array}$ & 125 & 6,0 \\
\hline Corporate Bonds & 365 & 17,7 \\
\hline Total & 2060 & 100,0 \\
\hline
\end{tabular}

There are several objective reasons for this situation:

1) a significant part of the infrastructure is designed to provide the necessary standard of living for the population and is not able to generate income for private investors (for example, the construction of urban roads or water supply systems).

2) a high capital intensity of many infrastructure facilities leads to their inability to generate cash flow that can interest a private investor (for example, the construction of airport runways, the construction of railways with low cargo turnover).

In the short term, a significant increase in budget spending on infrastructure is not forecasted, as most countries in the world are trying to reduce the budget shortage by reducing their costs for transport infrastructure.

Infrastructure projects are becoming increasingly attractive to investors. Despite the fact that the share of equity infrastructure financing was less than $2 \%$ earlier, this figure is growing from year to year. Thus, the amount of funds raised by infrastructure funds from 2004 to 2017 increased by $94 \%$, or by $\$ 37.6$ billion in absolute terms. The number of infrastructure funds involved in the share purchase of the infrastructure companies increased by 700 over the same period. The return on investment of such funds allocated for financing infrastructure facilities is on average $10-16 \%$ per annum.

The volume of bank lending to global infrastructure is about $\$ 160$ billion per year. The credit institutions are reducing the amount of long-term financing in the current conditions of economic instability. The cost of such financing increased by 1-2 percentage points on the average after the financial crisis of 2008 in the developing countries. Also, in order to reduce credit 
risks, credit organizations increased the required share of borrower own funds from 10 to $30 \%$. As a result of these steps, the weighted average cost of capital for an infrastructure project increased. In the near future, an increase in the number of risky projects in developing countries is forecasted, which may lead to a further increase in the cost of credit resources [3].

About $18 \%$ of investments in global infrastructure are attracted through the issue of corporate bonds. The volume of bonds issued by the infrastructure companies in 2015 amounted to about 365 billion dollars. [4]. The shares of the total volume of issued infrastructure bonds were distributed as follows: USA - $25 \%$, Europe $-25 \%$, and China - 15\%. There are companies in the energy sector $(50 \%)$ in the first place, and in the telecommunications sector - in the second place in terms of the volume of placed corporate bonds (25\%). There was a sharp increase in the volume of placed infrastructure bonds due to the high requirements for borrowers for long-term loans in the infrastructure sector during 2010-2015. The main investors in infrastructure bonds are pension funds, hedge funds and commercial banks [5].

Public-private partnerships are becoming one of the promising areas for coordinating the interests of investors and infrastructure companies. Today, its share in infrastructure financing is about $8 \%$. The governments of many countries are making efforts to develop it, which led to an increase in private infrastructure financing through PPP mechanisms to $\$ 180$ billion for 20042015 [7]. The disadvantage of using the PPP mechanisms for infrastructure financing is the unattractiveness of socially significant projects for them, including transport infrastructure projects.

One of the main trends in attracting private capital to infrastructure projects is the desire of governments to balance the risks and profitability of infrastructure projects by expanding the range of effective financing mechanisms. Thus, a guarantee of minimum profitability of infrastructure projects has been introduced in many countries [6]. In addition, the investors are provided with a minimum payment after compliting construction of the infrastructure facility, as well as 
protecting private investments from inflation.

An increase in private investments in Russian infrastructure projects is hindered by inadequate guarantees of return on investment. Therefore, to increase the attractiveness of Russian infrastructure projects for investors, it is necessary to ensure government assistance in achieving the required level of return on these projects. This can be achieved using the minimum guaranteed income mechanism, widely used in the world [8].

\section{Summary}

The global economic crisis of 2008-2009 complicated the implementation of the regional development goals, led to a reduction in investment and innovation costs, as well as exacerbated the structural weaknesses of the Russian regions [9]. Nevertheless, the difficult economic situation in the short term does not indicate the need to revise the goals of long-term development; rather, the bar is seriously "raised" for the pace and quality of economic development of the Russian regions. Solving the problems of accelerating the transition to the innovative development path of the Russian regions in the context of the impact of a number of external and internal challenges on Russia, complicating the achievement of goals, on the one hand, and dictating the need for even more intensification of efforts to solve the problems accumulated in the Russian regions, on the other hand.

The following problems are the main in the development of regional economic systems:

1) low efficiency of the implementation of the program-targeted management method.

2) lack of progressive structural changes in the economy of most Russian regions;

3) weak budgetary security and high debt burden. Thus, the debt of the Russian regions amounted to 2206 billion roubles as of 01.01.2019.

4) high dependence of the regional economy on the development of the raw materials sector. Thus, more than $50 \%$ of the value added and about $30 \%$ of the industrial production volume falls on the extractive industry in the Republic of Tatarstan.

5) low level of development of business activity in the peripheral 
areas of the region, which contributes to the growth of spatial polarization of Russian regions;

6) low level of material and technical base of production potential, which entails an increase in costs, a decrease in production competitiveness and profitability;

7) bias in the tax burden distribution - the bulk of tax revenues is generated from the taxation of legal entities, while it is generated from the taxation of individuals in many developed countries. Moreover, taking into account the measures taken in the field of tax policy, the overall level of the fiscal burden will remain at the level of $38-39 \%$ of GDP in the near future.

To solve all the accumulated problems, it is necessary to ensure structural changes in the economy of the regions, which shall be accompanied by infrastructural support for regional development, aimed at stimulating and attracting investments [10]. In this regard, it is necessary to assess the availability of infrastructure of regional economic systems in the context of federal districts or constituent entities of the Russian Federation, as well as to forecast structural changes in the economy, taking into account the high uncertainty of the prospects for the global economy.

\section{Conclusions}

In conclusion, it should be noted that the progressive structural dynamics of the development of regional economic systems depends on many factors as the whole. However, the most important of these are infrastructure support and effectiveness of regional socio-economic policies. Infrastructure development is becoming a prerequisite for economic growth, which is reflected in the strategic documents for the development of the region and its territories. In turn, a high level of infrastructure development helps to reduce investment risks in the region.

In the implementation of largescale infrastructure projects, priority should be given to the public-private partnerships, as direct private investments are the most effective and sustainable source of infrastructure development compared with other forms of investments.

The development of the Russian economy and individual regions depends on the level of infrastructure 
development and its innovative potential. Moreover, innovation is one of the driving factors for the infrastructure development.

In modern conditions, the infrastructure investments are financed mainly from the profits of enterprises and revenues from the federal budget, which is a consequence of the still weak development of the capital market in Russia. External sources of capital are not used much, while foreign capital is one of the least used sources of investment financing.

The main task of the state shall be to improve the investment climate and create favorable conditions for domestic and foreign investors. At the same time, the mechanisms of public-private partnership shall play a decisive role among the mechanisms of state influence on the development of the innovative component. Taking into account the increased interest of foreign investors, it can be said that the potential for attracting foreign direct investments in the infrastructure development is significant when creating the appropriate conditions.

\section{Acknowledgements}

780

The work is performed according to the Russian Government Program of Competitive Growth of Kazan Federal University.

This work is performed at the expense of the subsidy allocated to Kazan State University for the fulfillment of the state task in the field of scientific activity

(No. 26.8732.2017/BCH

(Russian: 26.8732.2017/БЧ)

\section{Bibliography}

World Investment Report, 2016 // United Nations Conference on Trade and Development (UNCTAD). - 2016. - P. 2$14,23-24$.

The infrastructure of Russia. Great ship asks great waters. Analytical review / Gazprombank. - Official website. - 2016. Access mode: www.gazprombank.ru/upload/iblock/20 9/gpbinfrustructure 09072016.pdfсвободный.

Between two partners [Electronic resource] / BRICSbusynessmagazine. Official site. $\quad-\quad$ URL: https://bricsmagazine.com/ru/articles/m ezh-dvuh-partnerov (reference date 
18.04.2017).

Official site of the RF Ministry of Economic Development.

URL:http://economy.gov.ru/minec/activ ity/sections/bizinmprove/roadmaps/201 6042101 (reference date 6.05.2017).

G.M. Galeeva, M.E. Ivanov, A.M. Vafin The innovative development of the industrial economy of Russia // Journal of economics and economic education research. - Volume 17, Special Issue 2. 2016. - p. 27-34.

Official statistics / Federal State Statistics Service - official website. 2017. Access mode: http://www.gks.ru, free.

Information on placed and attracted funds / Central Bank of the Russian Federation. - 2017. Access mode: http://cbr.ru/statistics/?PrtId=sors, free.

Recommendations on the implementation of public-private partnership projects in the regions of the Russian Federation / Public-Private Partnership Development Center. $2017 . \quad$ Access mode:
http://www.fa.ru/chair/gcp/Documents/

PeKQMeHflauHH.pdf, free.

Safiullin A.R, Shakirzyanov N.R, Ravzieva D.I., Infrastructure for regional development investment projects//Journal of Social Sciences Research. - 2018. - Vol.2018, Is.Special Issue 1. - P.281-284.

M. E. Ivanov, G. M. Galeeva Diversification of sources of external financing the real economy in terms of institutional transformation // Journal of economics and economic education research. Volume 17, Special Issue 2. 2016. - p. 415-422.

\section{$\mathrm{t}$}

